\title{
成人男性に発症した喉頭浮腫合併流行性耳下腺炎
}

$$
\text { 福 森崇之 }{ }^{1,2)} \text {. 宮川義 弘 }{ }^{2)} \cdot 丸 山 \text { 祐一郎 }^{1)} \cdot \text { 森田一 郎 }{ }^{1)}
$$

\section{A Case of Mumps with Laryngeal Edema}

\author{
Takayuki Fukumori ${ }^{1,2)}$, Yoshihiro Miyagawa ${ }^{2)}$ \\ Yuichiro Maruyama ${ }^{1)}$ and Ichiro Morita ${ }^{1)}$
}

\begin{abstract}
A 25 -year-old man who had a history of acute mumps infection at 3 years of age presented with a sore throat and high fever. A local otolaryngologist noticed the severe swelling of his salivary glands and laryngeal edema and the patient was referred to our hospital. A physical examination showed the severe bilateral swelling of the parotid and submandibular glands. Laryngeal fiberscopy indicated an advanced edematous change in the supraglottis. Enhanced computed tomography of the neck revealed swelling of the salivary glands and cervical lymph nodes with no evidence of abscess. Laboratory tests showed a leukocyte count of $6.6 \times 10^{3} / \mu \mathrm{L}$ (neutrophils $75.8 \%$, lymphocytes $17.8 \%$, and monocytes $5.8 \%$ ), a CRP level of $1.56 \mathrm{mg} / \mathrm{dL}$, and a serum Amylase level $992 \mathrm{IU} / \mathrm{L}$. After admission, tracheostomy was performed. The diagnosis of mumps was confirmed by the elevation of mumps-specific immunoglobulin $\mathrm{M}$ titers. Laryngeal edema associated with mumps is thought to be caused by lymphatic congestion, secondary to salivary gland enlargement due to inflammation. It is therefore essential to examine the airway by laryngoscopy in mumps patients with swelling of the submandibular and parotid glands.
\end{abstract}

Key words : mumps, laryngeal edema, tracheostomy, reinfection

\section{は じめに}

流行性耳下腺炎は, 耳下腺の有痛性腫脹と発熱を主症状 とする小児期の代表的な伝染性感染症である。 以前は, 一 度罹患すると終生免疫を得ると考えられていたが, 近年, 小児科医を中心に再感染の報告が行われ ${ }^{1 \sim 4)}$, 最近では, 耳鼻咽喉科医からの報告もみられるようになった ${ }^{5,6)}$. ム ンプスウイルス感染症の合併症には髄膜炎や睪丸炎等の他 に, 耳鼻咽喉科領域では感音難聴が有名である。喉頭浮腫 の合併は比較的稀ではあるが, 過去にも報告例があ $\eta^{7 \sim 20)}$, 特に顎下部の腫脹を伴う流行性耳下腺炎例では 注意が必要とされている ${ }^{9,10,12 \sim 14,17,18,20)}$. 今回, 流行性耳 下腺炎の既往を有する成人男性において, 著明な喉頭浮腫 により気管切開を要したムンプスウイルス感染症を経験し たため, 喉頭内視鏡所見の経時的変化を提示し, 文献的考 察を加えて報告する。

症例

症例 : 25 歳, 男性.

主訴：咽頭痛

現病歷：201X年 9 月 19 日, 咽頭痛を主訴に近医耳鼻咽 喉科を受診し，抗菌薬を処方された９月21日に再診し
た際に，両側頸部の腫脹，喉頭蓋の腫脹が認めたられたた め, 同日当科紹介受診となった。

既往歴： 3 歳時に流行性耳下腺炎罹患. ムンプス予防接 種歴なし.

生活歴：家族内感染等の明らかな接触歴なし.

初診時現症：体温 38 度, 両側耳下部から頸部にかけて 著明な腫脹を認めた（図 1 )。喉頭内視鏡検査では, 喉頭蓋 谷，喉頭蓋，両側披裂部及び周囲咽喉頭粘膜の蒼白な浮腫 状腫脹を認め, 発赤や白苔の付着は認めなかった（図2）.

血液検查所見：白血球数 $6690 / \mu \mathrm{L}$ (正常值 4000 $9000 / \mu \mathrm{L}$ )，CRP $1.56 \mathrm{mg} / \mathrm{dL}$ (正常值 $\leqq 0.1 \mathrm{mg} / \mathrm{dl}$ ）と軽 度上昇, 血清アミラーゼ $992 \mathrm{IU} / \mathrm{L}$ (正常值 40〜126 IU/L) と高值であった。

頸部造影 $\mathrm{CT}$ 検查所見: 両側耳下腺, 顎下腺の腫大及び 頸部皮下軟部組織の瀰漫性腫脹を認めた。両側耳下腺周囲 及び内頸静脈周囲を中心に, 複数の腫大したリンパ節を認 めた，また，喉頭蓋周囲粘膜の浮腫状変化を認めた（図 3 ).

経過：流行性耳下腺炎に伴う喉頭浮腫が疑われ, 緊急入 院の上，コハク酸ヒドロコルチゾンナトリウム $300 \mathrm{mg}$ の 点滴静注を開始した。浮腫の改善傾向を認めなかったた め, 同日, 局所麻酔下に気管切開術を実施した（図 4)。翌 日に実施した喉頭内視鏡検査所見では, 咽喉頭粘膜の浮腫

1) 自衛隊中央病院耳鼻咽喉科

2) 防衛医科大学校耳鼻咽喉科学講座

1) Department of Otolaryngology, Self Defense Forces Central Hospital

2) Department of Otolaryngology, Head and Neck Surgery, National Defense Medical College 


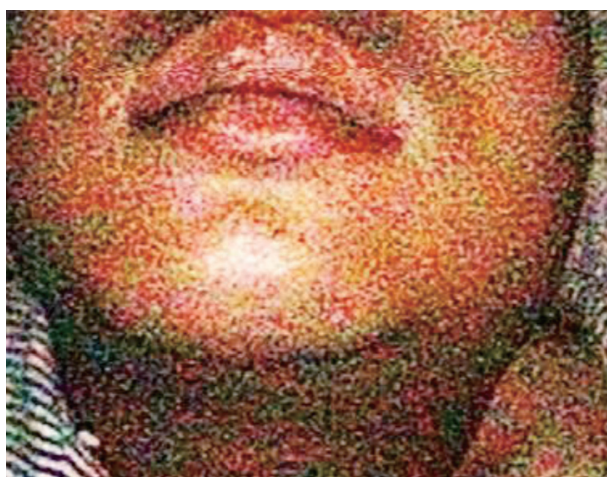

図 1 初診時頸部所見

両側耳下部から顎下部にかけて頸部腫 脹を認める。

は更に増悪を認め, 喉頭蓋は球状に腫大した（図 2)。その 後, 約 1 週間で, 頸部腫脹の軽減とともに喉頭浮腫の改善 を認めた。喉頭浮腫の消失を確認し，10月 1 日にカニュー レを抜去, 10 月 2 日に気管切開孔閉鎖術を施行し, 10 月 5 日に退院した。尚，9月 25 日の夜間より，発熱及び左睪 丸の疼痛を伴う鷄卵大の腫大をみとめた，当院泌尿器科に てムンプス精巣上体炎と診断され，片側のみの腫脹であり 無精子症になる可能性は低いと考えられた，特異的な治療

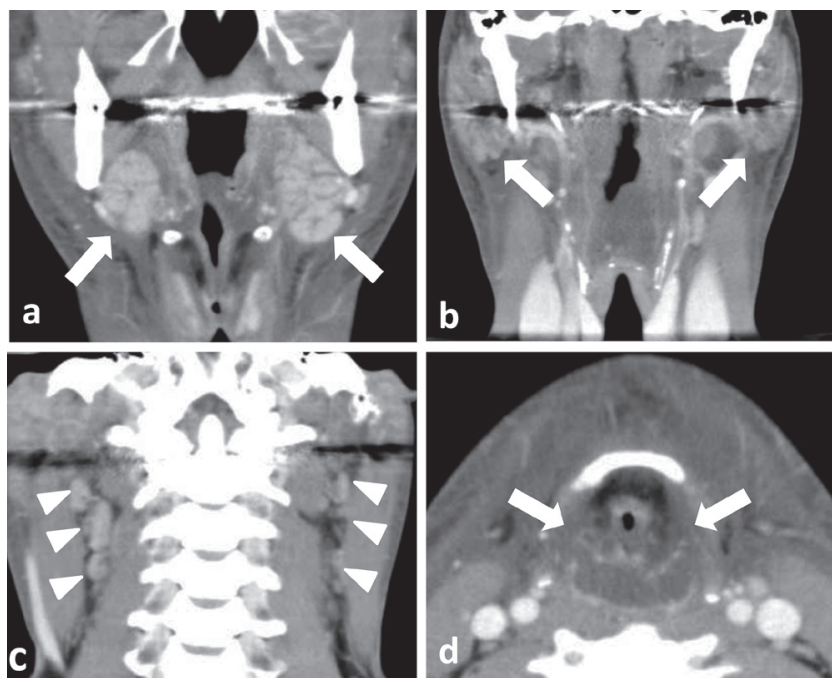

図 3 頸部造影 $\mathrm{CT}$

a, b : 両側耳下腺, 顎下腺の腫大を認める (矢印). $\mathrm{c}$ : 両側耳下腺周囲及び内頚静脈周囲を中心に, 複数の 腫大したリンパ節 (矢頭)を認める

$\mathrm{d}$ ：喉頭蓋周囲粘膜に高度の浮腫状腫脹 (矢印) を認める.

初診時
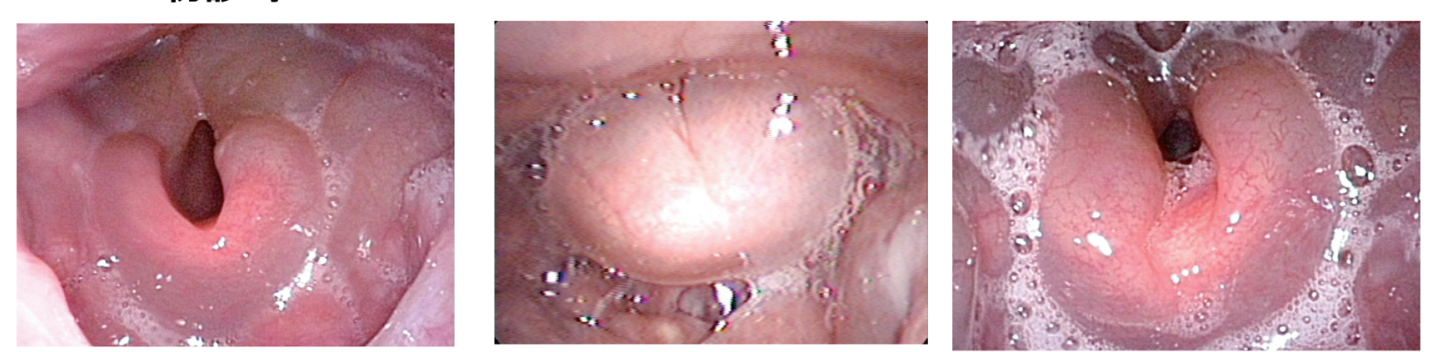

頸部腫脹

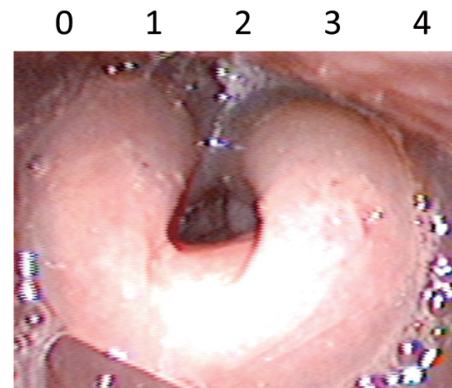

5POD $\begin{array}{llllll}5 & 6 & 7 & 8 & 9 & 10\end{array}$

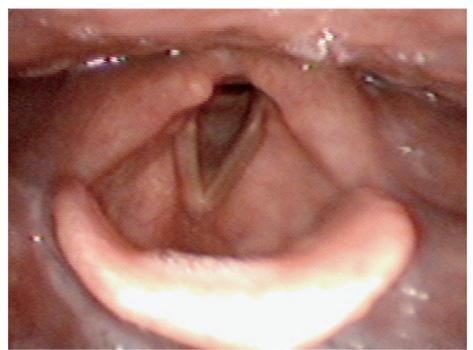

8POD
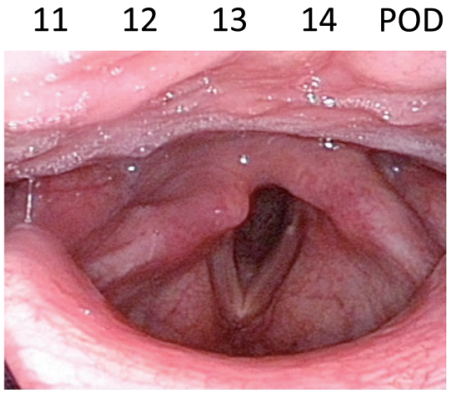

11POD

図 2 喉頭内視鏡検査経過

気管切開術後も浮腫は進行し，1PODには喉頭蓋は球状に腫大を認めたそその後, 頸部腫脹の軽減とともに浮 腫の改善を認めた。 


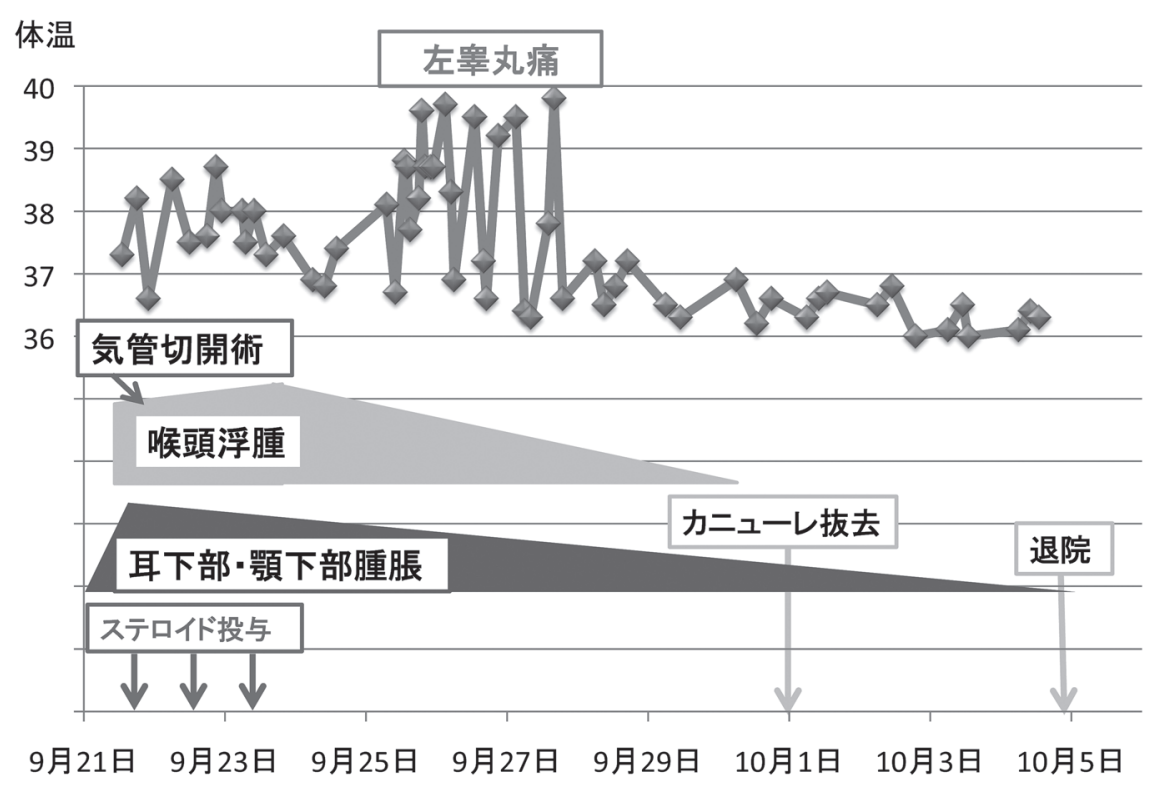

図 4 入院後経過

はなく，患部の冷却を指示され，左睪丸の腫脹及び疼痛は 発熱の軽快とともに消失した。初診時における抗体価測定 (EIA 法)において，ムンプス IgM抗体価 $7.22 \mathrm{MI}$ (陰性 0.8 未満，擬陽性 $0.80 \sim 1.20$, 陽性 1.21 以上）と陽性, 同 IgG抗体価は $3.5 \mathrm{MI}$ （㓌性 2.0 未満，擬陽性 $2.0 \sim 3.9$, 陽性 4.0 以上）と擬陽性であり，ムンプス感染症と診断し た. 尚, 回復期（10月5日）に測定したペア血清では, IgM抗体価は9.44 MI, IgG抗体価は 35.5 MI と IgGは 4 倍以上の上昇を認めた。

\section{考察}

流行性耳下腺炎はパラミクソウイルスの一種であるムン プスウイルスの感染により, 耳下腺の有痛性腫脹と発熱を 主症状とする感染症である。潜伏期は 16〜18日であり, 伝搬経路は飛沫感染や接触感染による。 上気道に感染し, 粘膜上皮で増殖した後に所属リンパ節でさらに増殖し，そ の後ウイルス血症を起こし全身に播種する ${ }^{21)}$ 。典型例で は, 耳下腺の腫脹は約 3 日後にピークに達し, その後 7 日 程度の経過で徐々に消退していく。ムンプスウイルスは, 大唾液腺組織や中枢神経系, 膵臓, 精巣の他に, 頻度は少 ないが甲状腺や卵巣，心臓，腎臓，関節液とも親和性が高 く, 主な合併症には髄膜炎 $(0.5 \sim 1 \%)$, 脳炎 $(0.02$ $0.03 \%$ ），睪丸炎（思春期以降の男性において 14～35\%), 卵巣炎 (約 $7 \%$ ) がある。耳鼻咽喉科領域の合併症として はムンプス難聴が有名であり，その頻度は本邦の調査によ れば $100 〜 1000$ 人に 1 人と決して低率ではないとされて いる ${ }^{22)}$.

流行性耳下腺炎に合併した喉頭浮腫は, 本症例も含める
と 29 例の報告がある (表 1 )。疫学的な発症率の検討はさ れていないが，いずれも成人例で，顎下部の腫脹を全例に 認めている点, 頸部の浮腫に左右差があるものにおいては 喉頭浮腫と患側が一致している点などが特徵的な所見であ る. また, 過去の報告例では全て日本国内での発症であり, 海外からの報告がないことは，ムンプスワクチンが任意接 種となっているために接種率が低く, 年間ムンプス感染者 数が他国と比して多い日本国内の状況との関連も一部の報 告では示唆されている ${ }^{13)}$. 喉頭浮腫の発症機序として, (1)頸部皮下軟部組織の腫脹による血管系あるいはリンパ管 系の循環障害によるうっ血性の浮腫 ${ }^{7)}$ が有力と考えられて いるが，他に，(2)咽喉頭粘膜局所におけるウイルス増 殖 ${ }^{10)}$, (3)顎下腺における炎症の波及をブロックする解剖 学的な構造物の欠如 ${ }^{20)}$ などの可能性が指摘されている. 本疾患に合併した同様の浮腫性病変として, 前胸骨浮腫の 報告 ${ }^{23,24)}$ があり, 成書の中では, Nelson Text book of Pediatrics ${ }^{21)}$ において, リンパ管閉塞による胸骨上の浮腫 が起こる可能性があると記載されている。過去の報告例に おいて, 全例に顎下部の腫脹を認めていること, 片側腫脹 例や左右差がある例において頸部及び喉頭の腫脹側の一致 率が高いことなどが, うっ血性浮腫による発生機序の妥当 性を支持するものと考えられる。本症例においても，蒼白 な浮腫状腫脹を示した喉頭内視鏡所見, 頸部造影 CT検査 における頸部リンパ節の著明な腫大や，周囲皮下軟部組織 の瀰漫性腫脹が認められたこと, 喉頭浮腫と頸部腫脹の経 過がほぼ一致していたことは, リンパ灌流障害によるうっ 血性変化に伴う所見として矛盾しない。 また，本症例では 強い咽頭痛を訴えていたが，過去の報告の中にも咽頭症状 
表 1 流行性耳下腺炎に合併した喉頭浮腫の報告 (本症例を含む)

\begin{tabular}{|c|c|c|c|c|c|c|c|c|c|c|c|c|}
\hline 報告者 & 報告年 & 年齢 & 性別 & $\begin{array}{l}\text { 罹患 } \\
\text { 歴 }\end{array}$ & $\begin{array}{c}\text { 予防 } \\
\text { 接種 } \\
\text { 歴 } \\
\end{array}$ & $\begin{array}{c}\text { 頸部腫脹 } \\
\text { 患側 }\end{array}$ & $\begin{array}{c}\text { 喉頭腫脹 } \\
\text { 患側 }\end{array}$ & $\begin{array}{c}\text { 頸部喉 } \\
\text { 頭腫脹 } \\
\text { 一致 }\end{array}$ & $\begin{array}{l}\text { 気管 } \\
\text { 切開 }\end{array}$ & $\begin{array}{c}\text { 気管切開 } \\
\text { までの } \\
\text { 日数 }\end{array}$ & $\begin{array}{c}\text { 急性期 } \\
\text { IgM }\end{array}$ & 急性期 IgG \\
\hline 加藤ら & 2002 年 & 34 & 女 & $(-)$ & $(-)$ & 両 & 両 & 0 & $(+)$ & 1 & $2.6(+)$ & 不詳 \\
\hline 同上 & 同上 & 32 & 女 & $(-)$ & $(-)$ & 両 & 左 & $\triangle$ & $(-)$ & $(-)$ & $1.0(-)$ & 不詳 \\
\hline 殿内ら & 2002 年 & 47 & 男 & $(-)$ & $(-)$ & 両 & 両 & 0 & $(+)$ & 0 & $0.83(-)$ & $37.6(+)$ \\
\hline Ishida 5 & 2006 年 & 43 & 女 & $(+)$ & $(-)$ & 左 & 左 & $\bigcirc$ & $(-)$ & $(-)$ & (+) 值不詳 & 不詳 \\
\hline 同上 & 同上 & 36 & 女 & $(+)$ & $(-)$ & 両 & 両 & $\bigcirc$ & $(+)$ & 2 & (+) 值不詳 & 不詳 \\
\hline 同上 & 同上 & 23 & 女 & $(-)$ & $(-)$ & 両 & 両 & $\bigcirc$ & $(+)$ & 0 & (+) 值不詳 & 不詳 \\
\hline 木村ら & 2006 年 & 26 & 男 & $(-)$ & $(+)$ & 両 (右側有意) & 右 & $\bigcirc$ & $(-)$ & $(-)$ & $8.82(+)$ & $10.2(+)$ \\
\hline 同上 & 同上 & 36 & 女 & $(-)$ & $(-)$ & 左 & 左 & $\bigcirc$ & $(-)$ & $(-)$ & $10.34(+)$ & $17.00(+)$ \\
\hline 松田ら & 2007 年 & 33 & 女 & $(-)$ & $(-)$ & 両 & 両 & $\bigcirc$ & $(-)$ & $(-)$ & (+) 值不詳 & 不詳 \\
\hline 小林ら & 2008 年 & 23 & 女 & $(-)$ & $(-)$ & 両 & 両 & $\bigcirc$ & $(-)$ & $(-)$ & $13.8(+)$ & $11.2(+)$ \\
\hline Sasaki ら & 2009 年 & 30 & 男 & $(-)$ & $(-)$ & 右 & 右 & $\bigcirc$ & $(-)$ & $(-)$ & (+) 值不詳 & $( \pm)$ \\
\hline 山村 & 2009 年 & 18 & 男 & $(-)$ & $(-)$ & 両 & 左 & $\triangle$ & $(-)$ & $(-)$ & $2.41(+)$ & 不詳 \\
\hline 山内ら & 2010 年 & 87 & 男 & $(-)$ & $(-)$ & 右 & 両 & $\triangle$ & $(-)$ & $(-)$ & $1.7(+)$ & $7.1(+)$ \\
\hline 松木ら & 2011 年 & 31 & 男 & $(-)$ & $(-)$ & 両 & 両 & $\bigcirc$ & $(-)$ & $(-)$ & （+）值不詳 & (+) 值不詳 \\
\hline 同上 & 同上 & 24 & 女 & $(-)$ & 不明 & 両 & 両 & $\bigcirc$ & $(-)$ & $(-)$ & $11.8(+)$ & $10.1(+)$ \\
\hline 同上 & 同上 & 46 & 女 & $(-)$ & $(-)$ & 両（左側有意） & 両 (左側有意) & $\bigcirc$ & $(-)$ & $(-)$ & $12.5(+)$ & $73.1(+)$ \\
\hline 同上 & 同上 & 76 & 女 & 不明 & 不明 & 両 & 左 & $\triangle$ & $(-)$ & $(-)$ & $6.5(+)$ & $9.1(+)$ \\
\hline 馬場ら & 2011 年 & 25 & 男 & $(-)$ & 不明 & 両 & 両 & $\bigcirc$ & $(-)$ & $(-)$ & 不詳 & 不詳 \\
\hline 同上 & 同上 & 31 & 女 & $(-)$ & 不明 & 両 & 両 & $\bigcirc$ & $(-)$ & $(-)$ & $6.67(+)$ & 不詳 \\
\hline 同上 & 同上 & 16 & 男 & $(-)$ & $(+)$ & 両 (右側有意) & 両 (右側有意) & $\bigcirc$ & $(-)$ & $(-)$ & $6.9(+)$ & 不詳 \\
\hline 同上 & 同上 & 32 & 女 & $(-)$ & 不明 & 両 & 両 & 0 & $(-)$ & $(-)$ & $1.17( \pm)$ & 不詳 \\
\hline 同上 & 同上 & 40 & 女 & $(-)$ & 不明 & 左 & 左 & $\bigcirc$ & $(-)$ & $(-)$ & $2.18(+)$ & 不詳 \\
\hline 松見ら & 2011 年 & 29 & 女 & $(-)$ & $(-)$ & 両 (左側有意) & 両 (左側有意) & $\bigcirc$ & $(-)$ & $(-)$ & $14.4(+)$ & $14.74(+)$ \\
\hline 熊井ら & 2012 年 & 39 & 男 & $(-)$ & 不詳 & 左 & 両 & $\triangle$ & $(-)$ & $(-)$ & $4.35(+)$ & $11.9(+)$ \\
\hline 同上 & 同上 & 23 & 女 & $(-)$ & $(-)$ & 左 & 左 & $\bigcirc$ & $(-)$ & $(-)$ & $12.0(+)$ & $35.3(+)$ \\
\hline 同上 & 同上 & 29 & 女 & $(-)$ & $(+)$ & 両 & 両 & $\bigcirc$ & $(+)$ & 0 & $9.55(+)$ & $14.8(+)$ \\
\hline 同上 & 同上 & 31 & 女 & $(-)$ & $(+)$ & 左 & 左 & $\bigcirc$ & $(-)$ & $(-)$ & $6.06(+)$ & $5.1(+)$ \\
\hline 川崎ら & 2013 年 & 18 & 男 & $(-)$ & $(-)$ & 両 (左側有意) & 両 & $\bigcirc$ & $(+)$ & 0 & $2.95(+)$ & $2.1(+)$ \\
\hline 本症例 & 2015 年 & 25 & 男 & $(+)$ & $(-)$ & 両 & 両 & 0 & $(+)$ & 0 & $7.22(+)$ & $3.5(+)$ \\
\hline
\end{tabular}

頸部喉頭腫脹一致は, 頸部と喉頭の腫脹側が完全に一致する場合は○とし, 頸部または喉頭腫脹のいずれかが両側など, 完全一致で

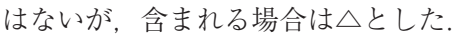

の記載の確認ができたものが 16 例 $(55 \%)$ 存在した.上気 道粘膜にウイルスが侵入した際に，咽喉頭粘膜局所におけ るウイルス増殖が強い症例があるのではないかと推察され る.

現在ムンプスに対して特異的な治療法はないために, 対 症療法が基本となる。喉頭浮腫の程度は症例によって異な り，副婜皮質ステロイド点滴投与等の保存的加療にて軽快 した症例もあるが, 本症例の様に喉頭浮腫の急激な増悪を 認める例もあり, 気道狭窄の程度に応じた適切な気道確保 が必要と思われる。

従来の見解では，ムンプスは一度感染またはワクチン接
種を受ければ終生免疫が得られ再発症することはないとさ れていたが，近年国内外でも小坚科領域を中心に再感染に ついての報告が行われ，耳鼻咽喉科医からの報告も散見さ れるようになってきている, 再感染の原因として, ウイル 又野生株の違いや genotypeの変異などに起因するウイル スの抗原性の違いによるものの他に, vaccine failure $(\mathrm{VF})^{25)}$ が挙げられる。病原診断は一般的に血清を用いて 酵素抗体法 (enzyme immunoassay, EIA) にて行われる。 初感染では急性期に IgM抗体が陽性化している事が多く, $\operatorname{IgG}$ 抗体価は急性期に低值であるが回復期に有意な上昇が 認められる，再感染に扔いては，急性期にIgM抗体は陰性 
表 2 小児におけるムンプス再感染診断指標

(1)ムンプスウイルス再感染の血清抗体価の指標（落合ら, 2007）

IgM抗体 $<2.5$ 抗体価 かつ IgG 抗体 $>25.8$ 抗体価

(2)急性耳下腺腫脹例に㧍けるムンプス抗体の特徵と診断（庵原ら, 2008)

\begin{tabular}{|c|c|c|c|c|c|}
\hline \multirow{2}{*}{ 既往歴 } & \multirow{2}{*}{ ワクチン歴 } & \multirow{2}{*}{ IgM抗体 } & \multicolumn{2}{|c|}{ IgG 抗体 } & \multirow{2}{*}{ 診断 } \\
\hline & & & 抗体価 & avidity & \\
\hline なし & なし & $+\sim++$ & + & 弱い & ムンプス初感染 \\
\hline なし & なし & $-\sim+$ & $+++*$ & 強い & ムンプス再感染 \\
\hline なし & なし & - & $-/+^{*}$ & 強い & ムンプス以外の原因 \\
\hline なし & あり & $+\sim++$ & + & 弱い & 一次性ワクチン不全 (VF) \\
\hline なし & あり & $-\sim+$ & +++ & 強い & 二次性ワクチン不全 (SVF) \\
\hline なし & あり & - & + & 強い & ムンプス以外の原因 \\
\hline あり & なし & - & + & 強い & ムンプス以外の原因 \\
\hline あり & なし & $-\sim+$ & +++ & 強い & ムンプス再感染 \\
\hline
\end{tabular}

*：ムンプスの既往はないが不顕性感染による IgG 抗体の陽転があった例

または弱陽性で, IgG抗体は高值を示すとされる，落合ら より, 再感染の診断指標（表 2) として, 初診時のムンプ スウイルス血清 IgM抗体価 $<2.5$ ， かつ同 IgG抗体 $>25.8$ が提唱されている．また， IgG抗体のウイルスとの結合力 の指標である avidity（結合活性）の測定が，再感染とワク チン接種後の免疫獲得不全 (primary vaccine failure, PVF) と一度獲得した免疫能の低下 (secondary vaccine failure, SVF）の鑑別に有用とされている（表 2)。再感染 及びSVFではIgG 抗体avidity が高く測定される。本症例 では，既往に関する情報は本人からの問診によるものでは あったが，初診時血清学的検查において IgG抗体が擬陽性 かつ, ペア血清にて IgG抗体が 4 倍以上の上昇を認めたこ とから既免疫獲得者であったと考えられる。また, 過去に 喉頭浮腫を来した流行性耳下腺炎 29 例の報告の中にも, ムンプス感染の既往または予防接種歴の有する患者が少な くとも 7 名は確認されている.この 7 名の検討では, 急性 期の $\operatorname{IgM} \cdot \operatorname{IgG}$ 抗体価は, 落合らの提言する $\operatorname{IgM}<2.5$ か つIgG > 25.8 以上とは必ずしも一致しておらず，畑中ら ${ }^{6)}$ も指摘するように，小児を対象とした調査結果をもとに作 成された診断基準をそのまま成人に適応するには検討が必 要であると考えられる。また，一般に再感染例では軽症例 が多いとされているが，ムンプス感染の既往または予防接 種歴のある喉頭浮腫を認めた 7 名に㧍ける気管切開実施率 は $42.9 \%$ であり，既往やワクチン接種歴のない 22 名にお ける $24.1 \%$ と比較して高率であり，ムンプスの既往やワ クチン接種歴の有無に関わらず，顎下部の腫脹が強く，浮 腫の進行が予想される場合には，気道の確保に慎重かつ迅 速な対応が必要である.

$$
\text { ま と め }
$$

流行性耳下腺炎の既往のある成人男性において, 喉頭浮
腫を伴うムンプス感染症を経験した。顎下部の腫脹を認め る例では，喉頭浮腫を念頭に置くとともに，浮腫は急激に 進行し，遷延する可能性があるため，十分な喉頭所見の経 過観察を行い, 気管切開を躊躇しないことが肝要と考え る。また，ムンプスの既往やワクチン接種歴があっても, 再感染の可能性も考慮する必要がある.

利益相反に該当する事項はない.

\section{文献}

1）落合 仁, 庵原利昭, 中野貴司：ワクチン歴によるム ンプス発症時の IgM抗体・IgG 抗体の比較検討。小児 科臨床 $60: 501-506,2007$.

2) 西野泰生：再感染ムンプス 7 症例の臨床ウイルス学的 検討。小児科臨床 $54: 1997-2003,2001$.

3）木所 稔：おたふくかぜの再感染と vaccine failureの 基礎. 臨床とウイルス 36:39-49, 2008.

4）庵原俊昭：おたふくかぜの再感染とVaccine failureの 臨床．臨床とウイルス 36:50-54, 2008.

5）畑中章生, 鎌田朋子, 本田圭二ほか：ムンプスウイル スの再感染と考えられた耳下腺炎の 3 症例。日耳 鼻 $115: 787-790,2012$.

6）畑中章生, 立石優美子, 本田圭二ほか：ムンプスウイ ルス再感染例の頻度と臨床的特徵。日耳鼻 117 ： 111-115, 2014.

7）加藤洋二 : 流行性耳下腺炎に合併した咽喉頭浮腫の成 人 2 例。日気食会報 $53: 37-39,2002$.

8) 殿内一弘, 山本昌彦, 吉田友秀ほか: 喉頭浮腫を合併 したムンプス例。耳鼻臨床 95:951-955, 2002 .

9) Ishida M, Fushiki H, Morijiri M et al : Mumps Virus Infection in Adults: Three Cases of Supraglottic 
edema. Laryngoscope 116 : 2221-2223, 2006.

10）木村美和子, 千原康裕, 二藤隆春ほか：喉頭浮腫を合 併したムンプスの 2 症例。日気食会報 $57: 502-507$, 2006.

11）松田和徳, 川淵 崇, 堀 洋二ほか：咽喉頭浮腫を合 併したムンプスの妊婦 1 症例. 徳島県立中央病院医学 雑誌 $28: 85-90,2007$.

12）小林俊樹, 平澤良征, 宇田川友克ほか：喉頭浮腫を合 併したムンプス感染症の 1 症例. 耳展 51:49-51, 2008.

13) Sasaki $T$, Tsunoda $K$ : Time to revisit munps vaccination in Japan?. Lancet 374: 1722, 2009.

14）山村一彦：ムンプスに伴う咽喉頭浮腫例. 耳鼻臨床 102: 1061-1064, 2009.

15）山内智彦, 市村恵一：87 歳で流行性耳下腺炎に罹患 し耳下腺内膿瘍と喉頭浮腫を合併した 1 例. 耳喉頭 頸 $82: 235-237,2010$.

16）松本 崇, 宮本俊輔, 永井浩巳ほか：咽喉頭浮腫を合 併したムンプス 4例の検討.耳鼻臨床 104：441446, 2011.

17）馬場有加, 大木雅文, 菊池 茂ほか：咽喉頭浮腫を合 併した流行性耳下腺炎の 5 症例. JOHNS 27：18211825, 2011.

18）松見文晶, 佐藤和則, 仲江川雄太ほか：気管切開によ り救命し得た流行性耳下腺炎に伴う喉頭浮腫例。耳喉
頭頸 83:329-332, 2011.

19）熊井㻟美, 岸部 幹, 吉田沙絵子ほか：喉頭浮腫を伴っ た流行性耳下腺炎の 4 例. 耳鼻臨床 105：277-284, 2012 .

20）川崎泰士, 和佐野浩一郎, 鈴木法臣ほか：急激な喉頭 浮腫を合併したムンプス感染症例. 耳鼻臨床 107:4346, 2014.

21) Wilbert M : Nelson Textbook of Pediatrics (18th ed), (Robert MK et al ed), 1078-1081, Sauders Company, Philadelphia, 2011.

22）川島慶之, 喜多村健, 井原一成ほか：ムンプス難聴の 疫学調査 (厚生労働科学研究 特定疾患対策研究事業 による急性高度難聴に関する調査研究). Audiol Jpn : 293-294, 2003.

23) Gellis SS, Peters M : Mumps with presternaledema. Bull Johns Hopkins Hosp 75 : 241, 1944.

24) Nussinovitch M, Cohen HA, Varsano I : Mumps with presternal edema-Gellis sign. Pediatr Infect Dis J 11 : 1069-1070, 1992.

25 ) 中山哲夫 : ウイルス抗原の変化とワクチン効果. 小児 内科 $41: 986-991,2009$.

別刷請求先 $\bar{\top}$ 154-8532 東京都世田谷区 1-2-24 自衛隊中央病院耳鼻咽喉科 福森崇之 